\title{
Improving the Education with Internal Quality Assurance System
}

\author{
$1^{\text {st }}$ Fatma Tresno Ingtyas ${ }^{1}, 2^{\text {nd }}$ Dina Ampera ${ }^{2}$, Siti Wahidah ${ }^{3}$, Farihah $^{4}$, Nuwairi Hilda ${ }^{5}$ \\ \{fatmatresno@unimed.ac.id ${ }^{1}$,dinaampera@unimed.ac.id ${ }^{2}$, sitiwahidah@unimed.ac.id ${ }^{3}$, \\ fahihah34@gmail.com ${ }^{4}$, nuwairyhilda@unimed.ac.id $\left.{ }^{4}\right\}$ \\ Departement Family Welfare Education. Univertitas Negeri Medan $n^{1,2,3,4,5}$
}

\begin{abstract}
Quality assurance is a series of processes and related systems to collect, maintains, and report data on the performance and quality of educators and education personnel, programs, and institutions. The quality assurance process identifies aspects of achievement and priority improvement provides data as the basis for planning and decision-making and helps build a culture of improvement. Sustainable.

This research aims to illustrate the implementation of the Internal Quality Assurance System (SPMI) as an effort to improve the quality of education in the PKK Department of the Unimed Faculty of Engineering. This study is qualitative research with case study methods. The research was conducted at the Department of Family Welfare Education (PKK) of the Faculty of Engineering Unimed, with the subject of the Department's Quality Assurance Team (TPMJ PKK). Data collection techniques: direct observation, document, and archival search, and interviews. The results of the study showed:(1) TPMJ policies and concepts in the form of academic documents and quality documents compiled by TPMJ PKK; (2) TPMJ PKK as coordinator in planning and carrying out learning in the PKK Department; (3) The implementation of TPMJ is carried out by the completion of the draft in the form of the PKK TPMJ Cycle; (4) Obstacles faced: leadership commitment, auditors, TPMJ PKK activities become routine; (5) Steps taken: providing quality assurance experts, building the spirit of guarantee; (6) Evaluation of the Implementation of TPMJ PKK is carried out every year; (7) Utilization of the results of the implementation of TPMJ PKK: building a culture of quality, accreditation; and (8) Development of TPMJ PKK implementation refers to the management of Badan Akreditasi Nasional standards Univercity.
\end{abstract}

Keywords: Quality Assurance, Internal Quality in the Department of Family Welfare Education (PKK)

\section{Introduction}

Education is an effort that is planned to realize the goal of learning so that students actively develop their potential in knowledge, self-control, personality, intelligence, noble morals, and the necessary skills themselves, society, nation and state, so that education isa necessity. Basic human. The problem of education that is felt today is the low quality of education in various types and levels of education.

The strategic role of higher education must pay attention to and apply the value of humanities and sustainable empowerment, as well as play a role in improving the competitiveness of the nation, and therefore higher education must develop science and technology and play a role to produce intellectual human beings, scientists, and/or Professional who is cultured and creative, tolerant, democratic, of strong character, and dares to defend the truth. Quality assurance of universities is a process of planning, fulfilling, controlling, and 
developing higher education standards to be consistently sustainable, so that internal and external stakeholders of universities, namely students, lecturers, educators, communities, businesses, professional associations, governments can get satisfaction with performance and output. College.

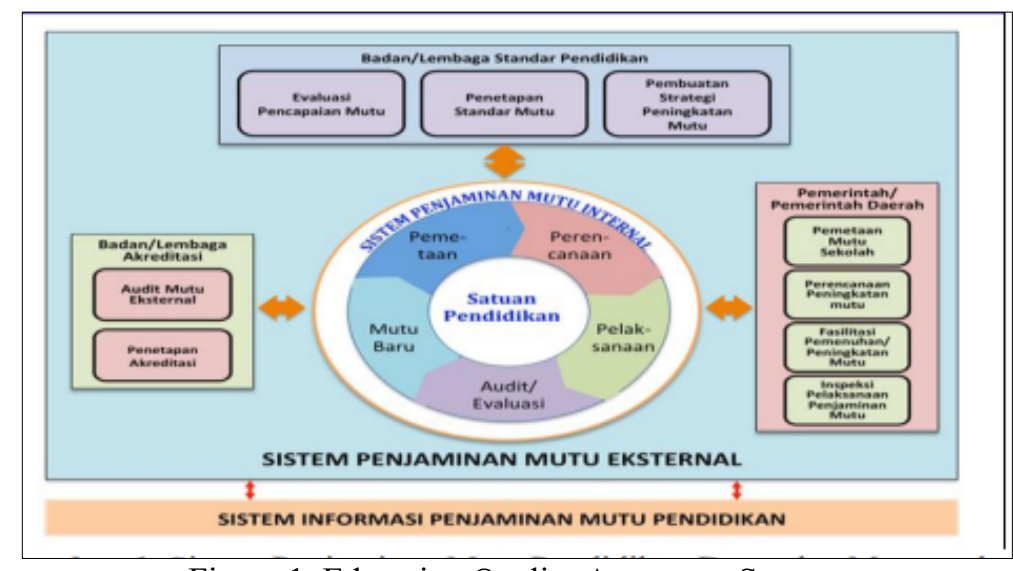

Figure 1. Education Quality Assurance System

The existence of accountability and transparency of the management of universities is a quality assurance activity, Higher Education Quality Assurance System (SPMPT) consisting of Internal Quality Assurance System (SPMI) developed by Tinggi University and External Quality Assurance System (SPME). done through accreditation. The government makes guidelines in the implementation of SMPI that aim to provide inspiration about various aspects that are generally contained in SPMI in a college.

Each college has different specifications, according to the vision and mission, organizational culture, organizational size, structure, resources, and leadership patterns. Implementation of the Internal Quality Assurance System is able to meet the demands of stakeholders needs, so SPMI must always be adjusted to continuous development. Medan State University in this case especially the Department of Family Welfare Education tried to pioneer and develop the concept of the Department's Quality Assurance Team (TPMJ). TPMJ in the PKK Department is carried out together under the Office of Quality Assurance (KJM University) in Unimed.

System quality assurance education in universities in accordance with the Quality Assurance Guidelines with the criteria must test the prerequisites, namely: commitment, paradigm shift, and mental attitude of higher education process actors, as well as the organization of quality assurance at the Department level. Quality management at the Department level field, among others; awareness of the actors of the education process about the importance of quality assurance as the needs of stakeholders is still low, the commitment of higher education actors to ensure and improve the quality of education is still lacking, understanding of the concept and implementation of quality assurance by the academic community has not been evenly distributed, governance and The quality assurance work mechanism has not been fully built, the empowerment of human resources, especially lecturers to support the quality assurance system has not been optimal, and the utilization of information and communication technology to support the internal quality assurance system is still maximum.

TPMJ activities that become routine cause no improvement that causes boredom. Implementation of TPMJ at the Department level often encounters problems, among others: 
(1) awareness of lecturers in the education process to the importance of quality assurance as the needs of stakeholders are relatively low; (2) understanding the concept of the quality assurance system of education by the academic community to improve the quality of education is still uneven; (3) The availability of human resources, especially auditors to support SPMI, is still not available; and (4) the implementation of TPMJ is often a routine making it difficult to measure the sustainability of continuous improvement. From the exposure of the background above, this research can be formulated the extent of the implementation of the internal quality assurance system in an effort to improve the quality of education in the Department of Family Welfare Education.

\section{Theory}

Quality definition is broadly a comprehensive picture and characteristic of a product or service that shows its ability to meet the needs, expectations, and satisfaction of customers. Oakland (1993) states that "Quality is used to signify 'excellence' of a product or service". Quality assurance is carried out through the determination, implementation, evaluation, control, and improvement of higher education standards. The quality of education in college is most often defined as "conformity for purpose", hence quality assurance refers to the policies, attitudes, actions and procedures necessary to ensure the quality is being maintained and improved. Such quality assurance is intended to ensure accountability and/or to bring improvements. Hedwig \& Polla (2006) explains that quality assurance becomes a routine, continuous work, and not an ad hoc activity. Therefore, supervision and evaluation need to be carried out continuously with the emphasis that this activity is not to look for errors, but to carry out continuous remedial actions. The quality assurance system will produce graduates of universities that are good, creative, innovative and able to create jobs with the science and technology owned.

The education quality assurance system is a system designed to improve the quality of education and sustainable through the stages of determination, implementation, evaluation, control, and improvement of educational standards. Quality assurance system is used to produce graduates who have science and technology as indicators of the success of quality education.

TQM aims to meet customer expectations, and if possible, exceed them. In addition to customer expectations constantly changing and increasing over time, and hence TQM is a philosophy of continuous improvement. TQM itself is not the ultimate goal, but the goal among those still going through a long process. This integrated quality management is applied in accordance with the provisions taking into account the dynamics of the development of the world of education and society, there will be changes that are quite effective for improving the quality of national education. The terms higher education and college are often perceived the same, while actually the two terms have different meanings. Higher education is education on the path of school education on higher education than secondary education. College is a unit of education that organizes higher education.

Markum (2007) states: "College is a unit of education that organizes higher education, namely education above the secondary education level, which includes diploma, undergraduate, master's, specialist, and doctoral education programs. Higher education is organized to prepare learners to become members of society who have academic and/or professional abilities that can apply, develop and / or create science, technology and/or arts".

Mishra (2007) stated: "Interim of level, higher education includes college and university teaching-leaning towards which students' progress to attain higher educational qualification. Higher education imparts in-depth knowledge and understanding so as to advance the student 
to new frontiers of knowledge in different walks of life (subject dominants). It is about knowing more and more about less and less. It develops the student's ability to question and seek truth and makes him/her competent to critique on contemporary issues. It broadens the intellectual powers of the individual within in a narrow specialization, but also give him/her a wider perspective of the world around". Higher education included in learning activities in colleges and universities directs students to achieve higher education qualifications. Higher education instills deep knowledge and understanding so that students can become reformers in the lives of society.

Higher education institutions are equipped with an organizational structure consisting of academic and non-academic sections, which are grouped into four areas/affairs, namely: academic affairs, student affairs, planning and development affairs, and business and financial affairs. Each field/business contributes to the social purpose of the institution in collecting, storing, and disseminating knowledge.

Universities as leaders of higher education autonomously must pay attention to the principles of accountability, transparency, non-profit, quality assurance, and effectiveness. The function and role of the college as: (a) a place of study of students; (b) a place of education for prospective leaders of the nation; (c) the center for the development of science and technology; (d) a place of study of virtue and moral power to seek and discover the truth; and (e) the center of the development of the nation's civilization. The development of universities is experiencing increasingly fierce competition, impacting globalization, advances in science and technology and the number of universities are increasing. In addition, the interest of high school graduates to go on to higher education is decreasing due to economic and practical considerations.

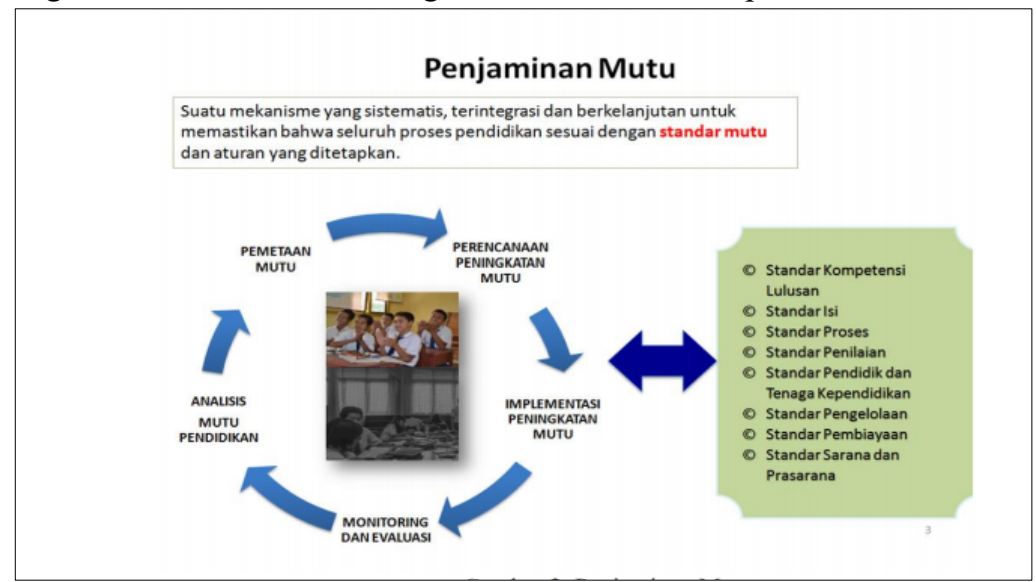

Figure 2. Internal and External Higher Education Quality Assurance System

The fundamental difference between internal and external quality assurance refers to policies and practices in which academic institutions evaluate themselves in order to improve the quality of education. External quality assurance refers to the above policies to ensure the quality of educational programs and institutions. Three approaches to assessing the quality of education in academic institutions, the first two approaches focus on external control, including processes derived from industrial models, while the third approach is internal assessment, empowering institutions and changes in organizational culture.

Such agreements: (1) professional accreditation based on the determination of criteria in determining academic quality prerequisites for allocating academic budgets and accreditations; (2) External quality monitoring relies on a committee of experts from outside the institution using the evaluation process to assess the quality of the programmed; and (3) academic audits 
are based on a combination of internal evaluations and reports on stakeholders. Academic audits assess the quality of educational processes and implementation and determine whether the activities necessary to produce and ensure quality improvement.

SPMI is an independent activity of the relevant college, so that the process is designed, run, and controlled by the relevant college without interference from the government. SPMI is run by universities internally to realize the vision and mission, and meet the needs of stakeholders through the implementation of Tridharma Perguruan Tinggi. The implementation of SPMI in universities is controlled through various quality control management models. External monitoring includes a wide range of quality evaluations conducted by external individuals or institutions for higher education institutions, including accreditation at the institutional level and teaching assessment programs and quality research, audits or reviews of institutional procedures and standard monitoring.

\section{Research Method}

This research uses a qualitative approach with Stu methods in cases, and in this study, the case studied was the successful implementation of the Department's Quality Min Team (TPMJ) in an effort to improve the quality of education and learning. This research was conducted at the Department of Family Welfare Education (PKK) Universitas Negeri Medan. The subject of this study is the Department's Quality Assessment Team (KJM) along with all the parts and personalities involved in learning in Program Study, (Culinary Education, Fashion Education, Cosmetology Education and Nutrition).

The new paradigm of education and learning systems that are oriented to quality recognizes four principles, namely (1) the principle of autonomy; (2) The principle of evaluation; (3) the principle of accountability, and (4) Princip accreditation. The new paradigm of education and learning systems can be used for all layers of learning, such as the authority or self-regulation on the autonomy of each study program can be classroom. The problem of quality assurance is visualized as follows.

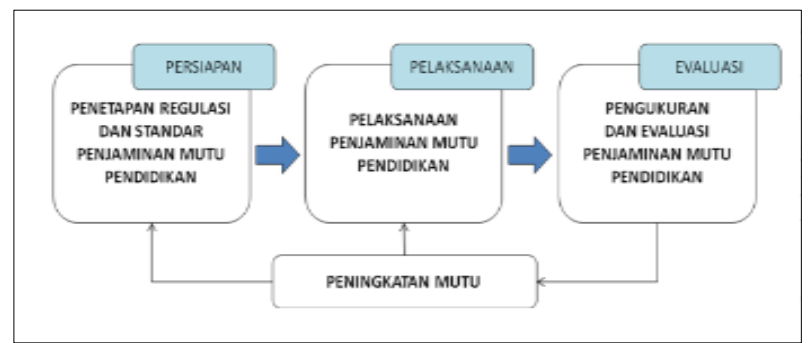

Fig 3: Problem solving of educational quality assurance

The data collected in the form of qualitative data derived from the results of data collection using data collection techniques in the form of questionnaires. Asa key instrument in this study are other supporting instruments such as observation guidelines, interview guidelines, and documentation guides. Researchers conduct direct observations of various activities on research subjects, observing and recording the infrastructure facilities of departments and study programs, human resources, as well as information and communication technology instruments and equipment utilized in the implementation and evaluation of TPMJ activities in the PKK Department.

Criteria used to determine the validity of data, namely the degree of trust (credibility), transferability, dependency and certainty. Researchers use a degree of trust with triangulation 
techniques, both in data collection methods and data sources. Triangulation in this study was carried out through the examination of data collection methods, namely observation data in the form of field records, documentation data in the form of letters and other written documents, and interview data in the form of interview transcripts. Triangulation is done by checking data on information sources in interviews, comparing the results of interviews from the Chairman and Vice Chairman of TPMJ.

Inductively is used in this study to draw conclusions on matters or events from data that have been collected through observation, interviews, and documentation, and general conclusions, with a data analysis using interactive models with major interrelated activities and occurring simultaneously, namely: data reduction, presentation of data and withdrawal of conclusions or verification. Presentation data by organizing data that has been reduced and presented separately between one stage with another stage. The results of research and discussion of quality assurance of education in the PKK Department is the process of establishing and fulfilling quality standards of education management consistently and sustainably, so that stakeholders (students, lecturers, education personnel, parents, government, the world of work, and other interested parties) get satisfaction.

\section{Research Results And Discussion}

The Department of Family Welfare Education (PKK) has four study programs, namely Culinary Education Study Program, Fashion Education, Cosmetology education and Nutrition. The Department of Family Welfare Education (PKK) is major chairman, 1 major secretary, 4 Heads of Study programs, 1 Chairman of Quality Assurance departments, 4 members of the quality research team, and 6 Heads of Laboratories. The Head of The Department has the main task as the person in charge of all academic and administrative activities. One secretary has a different task, namely as the person in charge of the academic and in charge of the general section.

The Department's Quality Assurance Team is tasked with assisting the head of the department in controlling the quality of graduates continuously. Then, the Head of the Laboratory serves as coordinator and accountability in each laboratory. In addition to the teams formed permanently, the head of the department is also assisted by the implementing units, namely lecturers who are given special tasks for an activity. In addition, the leadership element is assisted by employees as administrative implementers and academic implementing elements, namely lecturers.

The flow of authority and responsibility and cooperation will create a conducive situation, passionate, high work spirit and full of dynamics. These things are certainly very helpful in the achievement of the overall educational implementation goals. The secretary of the department and at the same time the chairman of the quality guarantor of the department has the task of assisting the chairman of the department/study program in the activities of the leadership, administration, supervisor and management of financial administration of the department / study program. Academic implementers (lecturers) are professionals and scientists with the main task of transforming and disseminating science and technology, through research education and community service. Administrative implementers have the task of carrying out general administration, equipment, finance, staffing and education in the department/study program. In addition to the above components, to support activities in the branch of science and technology in the department/study program.

This activity is carried out by referring to the Implementation of the Tridharma of Higher Education which begins with self-evaluation carried out both in the fields of: 1 . 
Education and teaching, 2. Research and development of scientific works, 3. Community service, and 4. Other supporting activities. This evaluation activity is realized in the form of the Department's Quality Assurance Team Report (TPMJ) which is assessed and verified with the principle of mutual compassion, compassion and foster care. This activity is expected to encourage the improvement of the professionalism of lecturers in the Department of Family Welfare Education (PKK) which will have implications for improving the academic atmosphere in the Department of Family Welfare Education (PKK). Evaluation is carried out periodically meaning that this evaluation is carried out at every fixed period that is once a year. This is to maintain accountability to stakeholders related to college performance.

The performance of Lecturers is the result of professional educators with the main task of transforming, developing and disseminating science, technology, and art through learning, research and community service. The main task of the lecturer is to carry out the Tridharma of universities with a workload of at least 12 (twelve) credits and at most 16 (sixteen) credits in each semester in accordance with their academic qualifications with the following provisions:

1. Doing education and teaching in college

2. Conducting research related to the field of science facilitated by universities, government institutions, other institutions, as well as independent research in accordance with the laws and regulations.

3. Perform community service organized by the relevant college or through other institutions in accordance with the laws and regulations

4. Conducting activities supporting the Tridarma of universities by actively engaging in student activities, universities and other academic activities in accordance with the legislation implementation of the description of lecturer workload (BKD).

5. Program Study in the Department of Family Welfare Education (PKK) has a role and responsibility in organizing the learning process in accordance with established standards and to participate in the creation of quality human resources through its vision and mission. Therefore, monitoring and evaluation of the learning process is needed in the Department of Family Welfare Education (PKK).

The process of learning and conducive academic atmosphere is carried out through the innovation of the learning process by using electronic facilities/infrastructure and relevant learning methods. To ensure a good learning process, regular monitoring of the implementation of learning activities, both regarding the frequency of lecturer/student attendance and the suitability of lecture substance in accordance with the Semester Learning Plan (RPS).

Monitoring Frills is done once in the semester, to evaluate the performance of lecturers is also used as a tool to evaluate how far the learning target has been met. Evaluation aims to improve the quality of learning including evaluation of: the way of delivery of material and the presence of lecturers, the material content of each course, student motivation, and difficulties arising in the process of interaction between lecturers and students. The interaction of lecturers and students in academic activities is not only in the learning process in the classroom, but can also be in research activities, community service, and non-academic activities (co-curricular/ extra-curricular, reasoning, etc.) with the aim to improve student soft-skills. High education must facilitate all these activities so that a conducive and quality academic atmosphere can be fulfilled with the facilities and infrastructure needed, among others: adequate student guidance rooms, reading rooms for students and lecturers, library facilities integrated with faculty libraries, as well as internet and social connections. lecturer-student interaction, and academic community. 
Table 1. Learning monitoring and evaluation instruments.

\begin{tabular}{|c|c|c|c|c|c|c|}
\hline No & Question & 5 & 4 & 3 & 2 & 1 \\
\hline & Early Learning Activities & & & & & \\
\hline 1 & $\begin{array}{l}\text { The lecturer explains the syllabus at the beginning } \\
\text { of the lecture. }\end{array}$ & 0.21 & 0.35 & 0.41 & 0.03 & 0 \\
\hline 2 & $\begin{array}{l}\text { The lecturer conveys information about the learning } \\
\text { objectives to be achieved. }\end{array}$ & 0.4 & 0.31 & 0.2 & 0.09 & 0 \\
\hline 3 & $\begin{array}{l}\text { Lecturers inform the competencies that must be } \\
\text { achieved by students. }\end{array}$ & 0.16 & 0.33 & 0.45 & 0.06 & 0 \\
\hline 4 & $\begin{array}{l}\text { The lecturer explains the outline of the material to } \\
\text { be studied during one semester at the beginning of } \\
\text { the lecture. }\end{array}$ & 0.25 & 0.34 & 0.41 & 0 & 0 \\
\hline 5 & $\begin{array}{l}\text { The lecturer informs the type of lecture assignments } \\
\text { that will be done in one semester. }\end{array}$ & 0.6 & 0.34 & 0.06 & 0 & 0 \\
\hline 6 & $\begin{array}{l}\text { The lecturer explains the relationship between his } \\
\text { course and other subjects. }\end{array}$ & 0.11 & 0.27 & 0.23 & 0.33 & 0.06 \\
\hline 7 & $\begin{array}{l}\text { The lecturer explains the rules contained in the } \\
\text { lecture contract. }\end{array}$ & 0.65 & 0.29 & 0.06 & 0 & 0 \\
\hline 8 & Lecturers convey reference sources used in lectures & 0.1 & 0.27 & 0.2 & 0.4 & 0.03 \\
\hline 9 & $\begin{array}{l}\text { The lecturer explains the components of the } \\
\text { assessment of learning outcomes. }\end{array}$ & 0.33 & 0.35 & 0.15 & 0.12 & 0.05 \\
\hline 10 & Lecturer explains the benefits of courses in life & 0.43 & 0.12 & 0.17 & 0.11 & 0.17 \\
\hline
\end{tabular}

The audit results show achievement of $88.55 \%$. Some of the good things in implementing this standard are 1) Every semester there is an upgrading of materials, methods, and even tools/media; 2) RPS is made by the lecturer in charge of the course and then discussed with a group of peer lecturers; 3) RPS is delivered online and/or directly to students at the first meeting at the beginning of the semester; 4) Prioritizing two-way interaction between students and lecturers, and 5) RPS is reviewed periodically and adjusted to the development of science and technology.

Suggestions for improvement proposed by the study program are; 1) Completing courses that do not have RPS 2) The RPS developed should contain student learning experiences embodied in a description of the tasks that must be done by students for one semester 3) it is necessary to improve the quality control activities of the learning process by monitoring, reviewing, improving periodically implementation of KBM 4) it is necessary to improve the quality control activities of the learning process with lecture material documents, instrument documents, and learning outcomes assessment results 5) study programs need to have standard procedures for evaluating student study results as well as continuous assessment and use to improve learning programs.

Table 2. Learning monitoring and evaluation instruments when learning is carried out.

\begin{tabular}{lllllll}
\hline No & Question & 5 & 4 & 3 & 2 & 1 \\
\hline & Learning Executor & & & & & \\
\hline 1 & The lecturer enters the class by greeting. & 0.21 & 0.35 & 0.41 & 0.03 & 0 \\
\hline 2 & $\begin{array}{l}\text { Lecturers connect learning materials with } \\
\text { student experiences. }\end{array}$ & 0.4 & 0.31 & 0.2 & 0.09 & 0 \\
\hline 3 & $\begin{array}{l}\text { Lecturers focus students attention on } \\
\text { attending lectures. }\end{array}$ & 0.16 & 0.33 & 0.45 & 0.06 & 0 \\
& & & & &
\end{tabular}




\begin{tabular}{|c|c|c|c|c|c|c|}
\hline 4 & $\begin{array}{l}\text { Lecturers provide learning motivation to } \\
\text { students. }\end{array}$ & 0.25 & 0.34 & 0.41 & 0 & 0 \\
\hline 5 & $\begin{array}{l}\text { Lecturers arouse students' interest in } \\
\text { learning to attend lectures. }\end{array}$ & 0.6 & 0.34 & 0.06 & 0 & 0 \\
\hline 6 & $\begin{array}{l}\text { Lecturers seek active participation of } \\
\text { students in lectures. }\end{array}$ & 0.11 & 0.27 & 0.23 & 0.33 & 0.06 \\
\hline 7 & $\begin{array}{l}\text { Lecturers strive for intensive student } \\
\text { learning interactions. }\end{array}$ & 0.65 & 0.29 & 0.06 & 0 & 0 \\
\hline 8 & Lecturers use various learning methods. & 0.1 & 0.27 & 0.2 & 0.4 & 0.03 \\
\hline 9 & $\begin{array}{l}\text { Lecturers use learning strategies that } \\
\text { encourage students' curiosity. }\end{array}$ & 0.33 & 0.35 & 0.15 & 0.12 & 0.05 \\
\hline 10 & $\begin{array}{l}\text { Lecturers arouse students' interest. to ask a } \\
\text { question. }\end{array}$ & 0.21 & 0.35 & 0.41 & 0.03 & 0 \\
\hline 11 & $\begin{array}{l}\text { Lecturers provide answers to student } \\
\text { questions. }\end{array}$ & 0.4 & 0.31 & 0.2 & 0.09 & 0 \\
\hline 12 & $\begin{array}{l}\text { Lecturers provide reinforcement to student } \\
\text { opinions. }\end{array}$ & 0.16 & 0.33 & 0.45 & 0.06 & 0 \\
\hline 13 & $\begin{array}{l}\text { Lecturers carry out classroom management } \\
\text { activities. }\end{array}$ & 0.25 & 0.34 & 0.41 & 0 & 0 \\
\hline 14 & $\begin{array}{l}\text { Lecturers deliver lecture material in a } \\
\text { structured way }\end{array}$ & 0.6 & 0.34 & 0.06 & 0 & 0 \\
\hline 15 & Lecturers master the lecture material. & 0.11 & 0.27 & 0.23 & 0.33 & 0.06 \\
\hline 16 & $\begin{array}{l}\text { Lecturers provide examples that are } \\
\text { relevant to the lecture material. }\end{array}$ & 0.65 & 0.29 & 0.06 & 0 & 0 \\
\hline 17 & $\begin{array}{l}\text { Lecturers apply various innovative learning } \\
\text { models. }\end{array}$ & 0.1 & 0.27 & 0.2 & 0.4 & 0.03 \\
\hline 18 & $\begin{array}{l}\text { Lecturers apply the learning model in a fun } \\
\text { way. }\end{array}$ & 0.33 & 0.35 & 0.15 & 0.12 & 0.05 \\
\hline 19 & $\begin{array}{l}\text { Lecturers provide constructive feedback to } \\
\text { students }\end{array}$ & 0.21 & 0.35 & 0.41 & 0.03 & 0 \\
\hline 20 & $\begin{array}{l}\text { Lecturers carry out student-centered } \\
\text { learning. }\end{array}$ & 0.4 & 0.31 & 0.2 & 0.09 & 0 \\
\hline 21 & $\begin{array}{l}\text { Lecturers give structured assignments to } \\
\text { students. }\end{array}$ & 0.16 & 0.33 & 0.45 & 0.06 & 0 \\
\hline 22 & $\begin{array}{l}\text { Lecturers provide guidance on assignments } \\
\text { done by students... }\end{array}$ & 0.25 & 0.34 & 0.41 & 0 & 0 \\
\hline 23 & $\begin{array}{l}\text { The lecturer returns the checked } \\
\text { assignments to the students }\end{array}$ & 0.6 & 0.34 & 0.06 & 0 & 0 \\
\hline 24 & $\begin{array}{l}\text { The lecturer concludes the lecture material } \\
\text { at the end of the lesson by involving } \\
\text { students }\end{array}$ & 0.11 & 0.27 & 0.23 & 0.33 & 0.06 \\
\hline 25 & $\begin{array}{l}\text { Lecturers use interesting and varied } \\
\text { learning media. }\end{array}$ & 0.65 & 0.29 & 0.06 & 0 & 0 \\
\hline 26 & $\begin{array}{l}\text { Lecturers encourage students to use } \\
\text { technology and communication in learning } \\
\text { activities. }\end{array}$ & 0.1 & 0.27 & 0.2 & 0.4 & 0.03 \\
\hline 27 & $\begin{array}{l}\text { Lecturers have authority in the learning } \\
\text { process }\end{array}$ & 0.33 & 0.35 & 0.15 & 0.12 & 0.05 \\
\hline 28 & $\begin{array}{l}\text { Lecturers are firm in applying the agreed } \\
\text { rules }\end{array}$ & 0.21 & 0.35 & 0.41 & 0.03 & 0 \\
\hline 29 & Lecturers are friendly. & 0.4 & 0.31 & 0.2 & 0.09 & 0 \\
\hline 30 & $\begin{array}{l}\text { 30The lecturer shows a wise and wise } \\
\text { attitude in making decisions. }\end{array}$ & 0.16 & 0.33 & 0.45 & 0.06 & 0 \\
\hline
\end{tabular}




\begin{tabular}{lllllll}
31 & $\begin{array}{l}\text { Lecturers are examples in attitude and } \\
\text { behavior. }\end{array}$ & 0.25 & 0.34 & 0.41 & 0 & 0 \\
\hline 32 & $\begin{array}{l}\text { Lecturers control emotions in carrying out } \\
\text { learning }\end{array}$ & 0.6 & 0.34 & 0.06 & 0 & 0 \\
\hline 33 & 0.11 & 0.27 & 0.23 & 0.33 & 0.06 \\
\hline 34 & $\begin{array}{l}\text { Lecturers are fair in treating students. } \\
\text { Attractive looking lecturer. }\end{array}$ & 0.65 & 0.29 & 0.06 & 0 & 0 \\
\hline 35 & $\begin{array}{l}\text { Lecturers are willing to accept suggestions } \\
\text { from students. }\end{array}$ & 0.1 & 0.27 & 0.2 & 0.4 & 0.03 \\
\hline 36 & $\begin{array}{l}\text { Lecturers get to know the students who } \\
\text { attend lectures. }\end{array}$ & 0.33 & 0.35 & 0.15 & 0.12 & 0.05 \\
\hline 37 & $\begin{array}{l}\text { Lecturers show tolerance for student } \\
\text { diversity. }\end{array}$ & 0.21 & 0.35 & 0.41 & 0.03 & 0 \\
\hline 38 & $\begin{array}{l}\text { Lecturers carry out lectures in accordance } \\
\text { with the allotted time. }\end{array}$ & 0.4 & 0.31 & 0.2 & 0.09 & 0 \\
\hline 39 & $\begin{array}{l}\text { Lecturers check student attendance every } \\
\text { lecture. }\end{array}$ & 0.16 & 0.33 & 0.45 & 0.06 & 0 \\
\hline 40 & $\begin{array}{l}\text { Lecturers appreciate students who attend on } \\
\text { time. }\end{array}$ & 0.25 & 0.34 & 0.41 & 0 & 0 \\
\hline 41 & $\begin{array}{l}\text { Lecturers use research results to support } \\
\text { lecture activities. }\end{array}$ & 0.6 & 0.34 & 0.06 & 0 & 0 \\
\hline 42 & $\begin{array}{l}\text { Lecturers take advantage of the results of } \\
\text { community service to support lecture } \\
\text { activities. }\end{array}$ & 0.11 & 0.27 & 0.23 & 0.33 & 0.06 \\
\hline
\end{tabular}

The results obtained in the even semester of 2020/2021 for the academic field were $84.7 \%$ of students stated that they were satisfied and very satisfied in getting services in the academic field. In terms of quality, the score is very good, but there are still complaints that are felt by students in the academic section. Sometimes lecturers are difficult to meet due to the interests of lecturers outside campus (lecturers attend meetings outside campus).

The results obtained in the even semesters of PBM activities, the average student stated that they were satisfied and very satisfied, namely $86.4 \%$ in receiving services at PBM (Teaching and Learning Processes), and in the quality figures, they entered very good numbers, only complaints were felt by the students. students, namely there are lecturers who teach not according to schedule, hopefully, this can be further improved because lecturers take part in meeting activities both internally and externally, this is due to online learning.

The results obtained in the even semester of learning in the laboratory, on average, students stated that they were satisfied and very satisfied, as many as $25 \%$ in receiving services in the laboratory, and in terms of quality, the numbers were not good, because of the current pandemic atmosphere, laboratory activities were also greatly reduced.

Another complaint felt by students was that there were no lockers in the laboratory so that students' bags and belongings were still carried anywhere, so they could interfere with practical activities in the laboratory room. The audit results show that several things in this standard still require attention, including 1) Lack of library materials (for certain study programs); 2) The number of facilities is limited, however, there have been efforts to increase it through educational donations from students; 3 ) There is no micro-teaching lab yet, so it is difficult for students to practice teaching; and 4) The maintenance program for tools and materials in the laboratory is in accordance with the needs, but unfortunately, the building for the laboratory is still lacking.

Table 3. Learning monitoring and evaluation instruments when assessing learning outcomes.

\begin{tabular}{lllllll}
\hline No & Question & 5 & 4 & 3 & 2 & 1 \\
\hline
\end{tabular}




\begin{tabular}{|c|c|c|c|c|c|c|}
\hline & Assessment of Learning Outcomes & & & & & \\
\hline 1 & $\begin{array}{l}\text { Lecturers use a variety of assessment } \\
\text { instruments to assess learning outcomes. }\end{array}$ & 0.12 & 0.16 & 0.33 & 0.23 & 0.16 \\
\hline 2 & Lecturers assess transparently. & 0.11 & 0.1 & 0.47 & 0.2 & 0.12 \\
\hline 3 & $\begin{array}{l}\text { The lecturer returns the exam answer sheet } \\
\text { that has been checked. }\end{array}$ & 0.02 & 0.12 & 0.38 & 0.33 & 0.15 \\
\hline 4 & $\begin{array}{l}\text { Lecturers provide opportunities for students } \\
\text { to confirm grades. }\end{array}$ & 0.12 & 0.19 & 0.43 & 0.17 & 0.09 \\
\hline 5 & Lecturers assess fairly and objectively. & 0.23 & 0.44 & 0.15 & 0.12 & 0.06 \\
\hline 6 & $\begin{array}{l}\text { The value given by the lecturer can trigger the } \\
\text { enthusiasm of students to improve learning } \\
\text { outcomes. }\end{array}$ & 0.49 & 0.22 & 0.12 & 0.14 & 0.03 \\
\hline 7 & $\begin{array}{l}\text { Lecturers carry out assessments in accordance } \\
\text { with the objectives of the lecture. }\end{array}$ & 0.34 & 0.45 & 0.11 & 0.08 & 0.02 \\
\hline 8 & The lecturer informs the exam schedule. & 0.89 & 0.11 & 0 & 0 & 0 \\
\hline 9 & $\begin{array}{l}\text { Lecturers allocate exam time according to the } \\
\text { number and level of difficulty of the } \\
\text { questions. }\end{array}$ & 0.67 & 0.23 & 0.1 & 0 & 0 \\
\hline 10 & $\begin{array}{l}\text { The lecturer gives an assessment of the } \\
\text { student's attitude }\end{array}$ & 0.8 & 0.2 & 0 & 0 & 0 \\
\hline 11 & Lecturers assess student skills. & 0.85 & 0.15 & 0 & 0 & 0 \\
\hline 12 & Lecturers assess student learning activities & 0.45 & 0.28 & 0.11 & 0.13 & 0.03 \\
\hline 13 & $\begin{array}{l}\text { The lecturer asks short questions to find out } \\
\text { the material that has not been mastered by } \\
\text { students }\end{array}$ & 0.15 & 0.21 & 0.49 & 0.11 & 0.04 \\
\hline
\end{tabular}

There are several opportunities for improvement that the Study Program can do: 1) To improve the quality of student Final Assignment assessment, Study Program can use Turnitin; 2) The application of an assessment for learning assessment system (assessment for learning), so as to obtain feedback that can affect the quality of learning; 3) The proportion of teaching time-sharing and carrying out activities outside of academics should be well-coordinated so that there is no overlap in the implementation.

\section{Conclusion}

The perpetrators of the higher education process in a college, both and led, must have a high commitment to always guarantee and improve the quality of higher education held. Without this commitment in all organizational lines of a college, surely the quality assurance of higher education in the college will run faltering, maybe even will not be successfully run.

There are various ways to choose from to gather commitment from all lines in a college, depending on the size, structure, resources, vision and mission, history, and leadership of the college. The system of governance has begun to form and is running well. This is indicated by the existence of secretaries who help the duties of the Prodi Chairman in carrying out their duties and obligations at the level program study. In addition, there is also one program study staff who helps with administrative and financial tasks.

Based on the results of monitoring and evaluation, the presence of lecturers in giving lectures is quite good, this is seen with $92 \%$ of lecturer attendance. While the presence of students is more than $85 \%$ in attending lectures. The achievement of this fine course can be seen from the percentage of achievements that have been in accordance with the syllabus. Hasil the performance of lecturers in the PKK Department is known that the teaching schedule of lecturers 
is well spread based on their areas of expertise. This can be accounted for because there are adequate lecturers so that they can divide the distribution of courses based on their field of expertise. However, the field of lecturer expertise is still held by lecturers in more than one field, this is because of the sufficient number of lecturers who are correlated with student comparisons, so that the group of lecturers and their fields of expertise are still impressed to join other fields. For the foreseeable future, program studies will strive to attract more students by making promotions more attractive to the community to attract students.

\section{References}

[1] Ditjen Dikti Depdiknas. Pedoman penjaminan mutu (quality assurance) pendidikan tinggi. Jakarta: Ditjne Dikti Depdiknas; 2003.

[2] Oakland JS. Total quality management: The route to improving performance. London: ButterworthHeinemann Ltd; 1995.

[3] Macdonald J. Understanding total quality management in a week, London: St Edmundsbury Press; 2005.

[4] Hedwig R, Polla G. Model sistem penjaminan mutu dan proses penerapannya di perguruan tinggi. Yogyakarta: Graha Ilmu Kemendiknas; 2006.

[5] Permendiknas Nomor 63 Tahun 2009 tentang sistem penjaminan mutu pendidikan.

[6] Markum ME. Pendidikan tinggi dalam perspektif sejarah dan perkembangannya di Indonesioa, Jakarta: Direktorat Jenderal Pendidikan Tinggi Departemen Pendidikan Nasional; 2007.

[7] Mishra S. Quality assurance in higher education: An introduction, Bangalore, India: National Assessment and Acreditation Council; 2007.

[8] Ditjen Dikti Kemendiknas. Sistem penjaminan mutu perguruan tinggi (SPM-PT). Jakarta: Ditjen Dikti Kemendiknas; 2010. 